\title{
Antihemophilic Factor, Human Recombinant
}

National Cancer Institute

\section{Source}

National Cancer Institute. Antihemophilic Factor, Human Recombinant. NCI Thesaurus.

Code C81123.

The recombinant form of human antihemophilic factor (AH)) (Factor VIII) with coagulation promoting activity. Antihemophilic factor binds to factor IXa in the coagulation cascade along with calcium and phospholipid. This complex converts factor $X$ to the activated form, factor Xa. In turn, factor $\mathrm{Xa/Va}$ complex activates thrombin, which cleaves fibrinogen into fibrin, eventually resulting in blood clot formation. 